Check for updates

Cite this: Chem. Sci., 2019, 10, 7600

¿ All publication charges for this article have been paid for by the Royal Society of Chemistry

\section{Structural and defect engineering of cobaltosic oxide nanoarchitectures as an ultrahigh energy density and super durable cathode for $\mathrm{Zn}$-based batteries $\dagger$}

\author{
Chunlin Teng, Fan Yang, Minghui Sun, Keshu Yin, Qintong Huang, Guangying Fu, \\ Chuanqi Zhang, (D) Xihong Lu (D)* and Jiuxing Jiang (D)*
}

\begin{abstract}
The key challenges of aqueous Zn-based batteries (ZBBs) are their unsatisfactory energy density and poor lifespan, mainly arising from the low capacity and irreversibility of the cathode materials. Herein, a threedimensional (3D) ordered mesoporous nanoarchitecture cobaltosic oxide $\left(\mathrm{M}-\mathrm{CO}_{3} \mathrm{O}_{4}\right)$ with rich oxygen

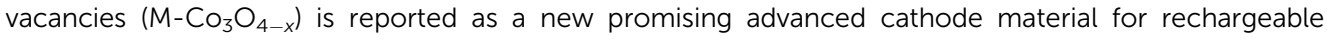
ZBBs. The experimental results and DFT calculations reveal that the energy storage capacity is significantly enhanced by the synergistic effect of mesopores and oxygen vacancies. Benefiting from the merits of a substantially fast ion diffusion channel, high electrical conductivity, large active surface area, strong $\mathrm{OH}^{-}$adsorption capacity and stable structure, the fabricated $\mathrm{M}-\mathrm{CO}_{3} \mathrm{O}_{4-x} / / \mathrm{Zn}$ battery delivers a remarkable capacity of $384 \mathrm{~mA} \mathrm{~h} \mathrm{~g}^{-1}$ at $1.0 \mathrm{~A} \mathrm{~g}^{-1}$ which even rises up to $420 \mathrm{~mA} \mathrm{~h} \mathrm{~g}$ after cycling activation with an ultrahigh energy density of $722.4 \mathrm{~W} \mathrm{~h} \mathrm{~kg}^{-1}$ (based on the weights of the cathode active material), which outperforms most of the previously reported aqueous ZBBs. More impressively, the $\mathrm{M}-\mathrm{CO}_{3} \mathrm{O}_{4-x} / / \mathrm{Zn}$ battery exhibits extraordinary cycling stability, both at $1 \mathrm{~A} \mathrm{~g}^{-1}$ and $10 \mathrm{~A} \mathrm{~g}^{-1}$ without any decay of capacity after 6000 and 60000 cycles, respectively, and such high cycling stability is reported for the first time in ZBBs. The ultrahigh energy and superlong lifespan of aqueous ZBBs could make it satisfy some practical energy demands.
\end{abstract}

Received 17th April 2019

Accepted 22nd June 2019

DOI: $10.1039 / c 9 s c 01902 b$

rsc.li/chemical-science

\section{Introduction}

Cost-effective, environmentally friendly, and safe advanced energy-storage devices are critical for future widespread utilization of renewable energy sources (such as wind, wave, and solar), power portable electronics and electrified vehicles. ${ }^{1-3}$ Among various alternative options, aqueous zinc-based batteries (ZBBs) are particularly attractive due to their unique properties of high safety, low-cost, extensive zinc global stockpile, environmental benignity, low $\mathrm{Zn} / \mathrm{Zn}^{2+}$ redox potential (about $0.76 \mathrm{~V} v s$. the standard hydrogen electrode (SHE)), ${ }^{4,5}$ and high theoretic capacity of the zinc metal electrode $(820 \mathrm{~mA}$ $\left.\mathrm{h} \mathrm{g}^{-1}\right){ }^{4,6}$ However, the widespread application of these ZBBs is still seriously impeded by two main challenges. The first one is the poor lifespan ( $<2000$ cycles), which mainly derives from the

MOE Key Laboratory of Bioinorganic and Synthetic Chemistry, Environment and Energy Chemistry, School of Chemistry, Sun Yat-Sen University, Guangzhou 510275, People's Republic of China.E-mail: luxh6@mail.sysu.edu.cn; jiangjiux@mail.sysu. edu.cn

$\dagger$ Electronic supplementary information (ESI) available: Additional morphology characterization, XPS, nitrogen adsorption-desorption data, electrochemical characterization of the samples and calculation formulas. See DOI: $10.1039 / \mathrm{c} 9 \mathrm{sc} 01902 \mathrm{~b}$ dendritic formation of the $\mathrm{Zn}$ anode, and the dissolution or huge volume change of the cathode during charging-discharging processes..$^{5,7,8}$ The other one is the unsatisfactory energy density as a result of the much lower capacity of the cathode than the Zn anode. ${ }^{9}$ The exploitation of high-capacity and durable cathode materials is very hopeful to address these two issues. Currently, various kinds of transition metal oxides including $\mathrm{NiO}, \mathrm{MnO}_{2}, \mathrm{Co}_{3} \mathrm{O}_{4}, \mathrm{~V}_{2} \mathrm{O}_{5}$ etc. ${ }^{7,9-15}$ have been widely investigated as cathodes in ZBBs because of their abundant oxidation states that are available for reversible redox reactions and extensive global stockpile of the most transition metal oxides. Particularly, spinel cobaltosic oxide $\left(\mathrm{Co}_{3} \mathrm{O}_{4}\right)$ has received ever-growing interest as a promising $\mathrm{ZBB}$ electrode material because of its unique advantages of high theoretical capacity (446 mA h g${ }^{-1}$ ), low-cost, earth abundance, and high thermodynamic stability. For instance, Wang et al. ${ }^{7}$ constructed a $\mathrm{Zn} / / \mathrm{Co}_{3} \mathrm{O}_{4}$ battery by using ultrathin $\mathrm{Co}_{3} \mathrm{O}_{4}$ nanosheets as the cathode, which displayed a capacity of $162 \mathrm{~mA} \mathrm{~h}$ $\mathrm{g}^{-1}$ at $1 \mathrm{~A} \mathrm{~g}^{-1}$ and $80 \%$ capacity retention after 2000 cycles. A high-voltage $\mathrm{Co} / / \mathrm{Zn}$ battery with a high discharge capacity of $205 \mathrm{~mA} \mathrm{~h} \mathrm{~g}^{-1}$ and a remarkable energy density of $360.8 \mathrm{Wh}$ $\mathrm{kg}^{-1}$ at $0.5 \mathrm{~A} \mathrm{~g}^{-1}$ was recently demonstrated by employing a $\mathrm{Co}(\mathrm{III})$ rich- $\mathrm{CO}_{3} \mathrm{O}_{4}$ nanorod material as the cathode. ${ }^{10}$ This 
battery also yielded fairly good cycling stability of $92 \%$ capacity retention after 5000 charge-discharge cycles. In spite of these advances, due to the inherently poor conductivity (semiconducting nature), limited active site exposure and huge volume change of $\mathrm{Co}_{3} \mathrm{O}_{4}$, the energy density and cyclic life of these current $\mathrm{Zn} / / \mathrm{Co}_{3} \mathrm{O}_{4}$ batteries are still far from practical application. To sum up, it is still a great challenge and highly attractive to explore new $\mathrm{Co}_{3} \mathrm{O}_{4}$ cathodes with ultrahigh capacity and excellent durability for ZBBs.

In this work, we report a structure and defect engineered $\mathrm{Co}_{3} \mathrm{O}_{4}$ architecture with unprecedented electrochemical activity as a robust cathode for $\mathrm{Zn} / / \mathrm{Co}_{3} \mathrm{O}_{4}$ batteries. This $\mathrm{Co}_{3} \mathrm{O}_{4}$ architecture composed of three-dimensional (3D) ordered mesopores and abundant oxygen vacancies is facilely prepared through a simple nanocasting method and post-thermal-reduction treatment (denoted as $\mathrm{M}-\mathrm{Co}_{3} \mathrm{O}_{4-x}$ ). The characteristic 3D mesoporous morphology design provides a large surface area, enhanced permeability and shortened ion transport distance. ${ }^{\mathbf{1 6 , 1 7}}$ In addition, the appropriate channel and stable structure are beneficial to alleviate the large volume changes during the charge/discharge process, ${ }^{18}$ which are favorable to gain a longer cycling life. ${ }^{\mathbf{1 6}, 19}$ Meanwhile, the creation of oxygen vacancies within the metal oxide is an effective approach to improve the conductivity and achieve more active sites for surface redox reactions in electrodes, ${ }^{\mathbf{2 0 , 2 1}}$ which is verified by both experimental and density functional theory (DFT) studies. As a result, the as-fabricated ZBB based on the optimized M$\mathrm{Co}_{3} \mathrm{O}_{4-x}$ cathode delivers an admirable capacity of $420 \mathrm{~mA} \mathrm{~h} \mathrm{~g}^{-1}$ at $1.0 \mathrm{~A} \mathrm{~g}^{-1}$ and an ultrahigh energy density of $722.4 \mathrm{~W} \mathrm{~h} \mathrm{~kg}^{-1}$ (based on the weights of $\mathrm{M}-\mathrm{Co}_{3} \mathrm{O}_{4-x}$ ) after cycling activation. Moreover, the rechargeable $\mathrm{M}-\mathrm{Co}_{3} \mathrm{O}_{4-x} / / \mathrm{Zn}$ battery possesses extraordinary cycling stability without any capacity decay after 6000 and 60000 cycles at $1 \mathrm{~A} \mathrm{~g}^{-1}$ and $10 \mathrm{~A} \mathrm{~g}^{-1}$, respectively. All
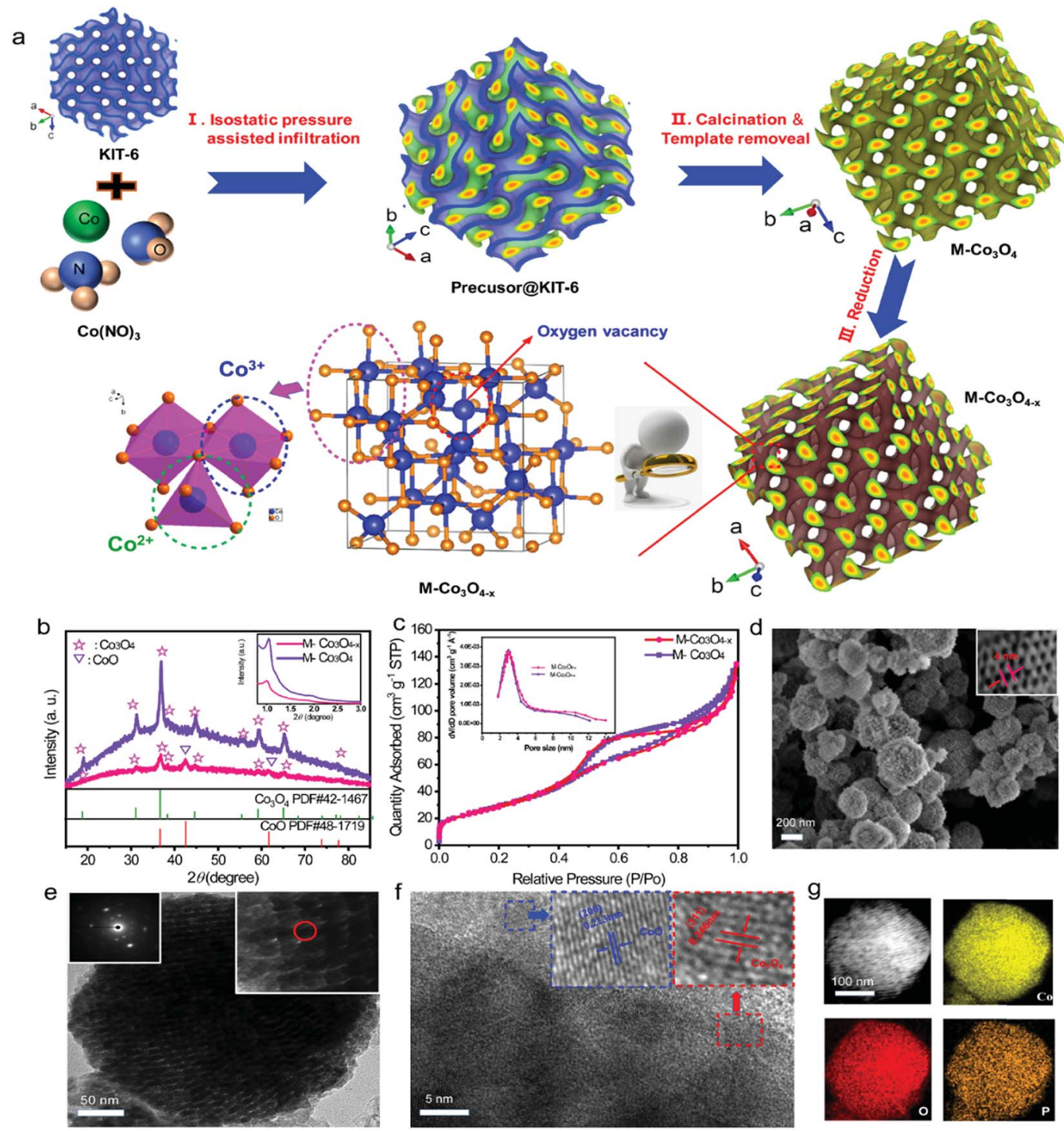

Fig. 1 (a) Schematic illustration of the synthesis procedure of $\mathrm{M}-\mathrm{CO}_{3} \mathrm{O}_{4}$ and $\mathrm{M}-\mathrm{CO}_{3} \mathrm{O}_{4-x}$ samples, (b) XRD patterns, (c) $\mathrm{N}_{2}$ sorption isotherms and pore size distributions (PSDs) of $\mathrm{M}-\mathrm{CO}_{3} \mathrm{O}_{4}$ and $\mathrm{M}-\mathrm{CO}_{3} \mathrm{O}_{4-x}$. (d, e and f) SEM, TEM and HRTEM images of $\mathrm{M}-\mathrm{CO}_{3} \mathrm{O}_{4-x}$ ( $(\mathrm{g})$ high-angle annular dark-

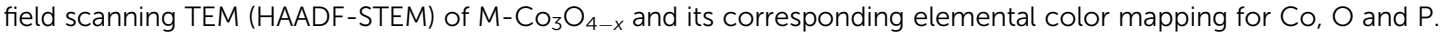


of the results imply that the porous $\mathrm{M}-\mathrm{Co}_{3} \mathrm{O}_{4-x}$ has high potential for real application in high-performance ZBBs.

\section{Results and discussion}

The $\mathrm{M}-\mathrm{Co}_{3} \mathrm{O}_{4-x}$ architecture is fabricated by a facile isostatic pressure assisted nanocasting method, which we first designed and has been used in the preparation of zeolite templated carbon (ZTC), ${ }^{22}$ and following reduction treatment under a reductive steam (Fig. 1a). Typically, an ordered mesoporous $\mathrm{Co}_{3} \mathrm{O}_{4}\left(\mathrm{M}-\mathrm{Co}_{3} \mathrm{O}_{4}\right)$ architecture is synthesized by using a high isostatic pressure assisted nanocasting method under $300 \mathrm{MPa}$ with mesoporous KIT-6 zeolite as a hard template (Fig. S1 $\dagger$ ). Then, in order to induce oxygen vacancies, the as-obtained $\mathrm{M}$ $\mathrm{Co}_{3} \mathrm{O}_{4}$ is calcined in the presence of a $\mathrm{NaH}_{2} \mathrm{PO}_{2} \cdot \mathrm{H}_{2} \mathrm{O}$ steam at $250{ }^{\circ} \mathrm{C}$ (see detailed methods in the Experimental section). Fig. 1b compares the typical X-ray diffraction (XRD) patterns of the $\mathrm{M}-\mathrm{Co}_{3} \mathrm{O}_{4}$ and $\mathrm{M}-\mathrm{Co}_{3} \mathrm{O}_{4-x}$ samples. Besides the diffraction peaks of $\mathrm{Co}_{3} \mathrm{O}_{4}$ (PDF\#42-1467, FD-3m(227)), two additional weak diffraction peaks at $42.6^{\circ}$ and $62^{\circ}$ that correspond to the (200) and (220) planes of the CoO phase (PDF\#48-1719) are observed for the $\mathrm{M}-\mathrm{Co}_{3} \mathrm{O}_{4-x}$ samples, indicating that a small amount of $\mathrm{Co}^{3+}$ has been successfully reduced to $\mathrm{Co}^{2+}$ during the thermal-reduction process. It is well known that oxygen vacancies are easily formed in $\mathrm{Co}_{3} \mathrm{O}_{4}$, accompanied by the transformation of $\mathrm{Co}^{3+}$ to $\mathrm{Co}^{2+} \cdot{ }^{21,23}$ The inset in Fig. 1b shows the corresponding low-angle powder XRD pattern. Two resolved peaks at around $1^{\circ}$ and $1.9^{\circ}$ assigned to (211) and (332) reflections suggest that the as-obtained sample is successfully replicated from the template KIT- 6 topology. ${ }^{24}$ The mesoporous structure of $\mathrm{M}-\mathrm{Co}_{3} \mathrm{O}_{4}$ and $\mathrm{M}-\mathrm{Co}_{3} \mathrm{O}_{4-x}$ samples is further confirmed by $\mathrm{N}_{2}$ sorption. In Fig. 1c, both of them show similar obvious hysteresis loops, which clearly supports the mesoporous structure conclusion. The pore size distribution (PSD) plot inserted in Fig. 1c shows the majority mesopore sizes of 2-5 nm for both samples. In addition, high BrunauerEmmett-Teller (BET) surface areas of $143 \mathrm{~m}^{2} \mathrm{~g}^{-1}$ and $139 \mathrm{~m}^{2}$ $\mathrm{g}^{-1}$ are obtained for the pristine $\mathrm{M}-\mathrm{Co}_{3} \mathrm{O}_{4}$ and $\mathrm{M}-\mathrm{Co}_{3} \mathrm{O}_{4-x}$ samples (Table $\mathrm{S} 1 \dagger$ ), respectively. Both the similar pore size and BET surface area indicate that the morphology and mesoporous features of $\mathrm{M}-\mathrm{Co}_{3} \mathrm{O}_{4}$ are well preserved after the thermalreduction treatment.

The scanning electron microscopy (SEM) and transmission electron microscopy (TEM) images of $\mathrm{M}-\mathrm{Co}_{3} \mathrm{O}_{4-x}$ (Fig. 1d and e) show a round pie shaped morphology with diameters of around 100-250 $\mathrm{nm}$ and ordered mesopores throughout the whole architecture. The higher resolution image indicates that the nanoporous architectures are constituted by interconnected sphere nanoparticles, which give rise to a regular porous texture. The average pore diameter is around $4 \mathrm{~nm}$, in good agreement with the PSD results of the $\mathrm{N}_{2}$ sorption test (Fig. 1c inset), which is beneficial for the penetration of the electrolyte and fast ion transport. After reduction treatment, the morphology of $\mathrm{M}-\mathrm{Co}_{3} \mathrm{O}_{4-x}$ remains intact (Fig. 1d, e and $\mathrm{S} 2 \dagger$ ), which implies a strong connection between the nanoparticles. The selected-area electron diffraction (SAED) analyses further confirm the polycrystalline nature of pristine $\mathrm{M}-\mathrm{Co}_{3} \mathrm{O}_{4}$ and $\mathrm{M}$ $\mathrm{Co}_{3} \mathrm{O}_{4-x}$ (Fig. 1e, $\mathrm{S} 2 \mathrm{~b} \dagger$, inset). High-resolution TEM (Fig. 1f) clearly reveals the well-resolved lattice fringes of 0.213 and 0.246 $\mathrm{nm}$, corresponding to the (200) plane of CoO (PDF\#48-1719) and the (311) plane of $\mathrm{Co}_{3} \mathrm{O}_{4}$ (PDF\#42-1467), ${ }^{19,25,26}$ consistent with the XRD results. Besides, the energy-dispersive spectroscopy (EDS) mapping demonstrates that $\mathrm{Co}, \mathrm{O}$ and $\mathrm{P}$ elements are distributed homogeneously (Fig. 1g).

The evolution of the chemical states of Co and $\mathrm{O}$ species in $\mathrm{M}-\mathrm{Co}_{3} \mathrm{O}_{4-x}$ is identified by X-ray photoelectron spectroscopy
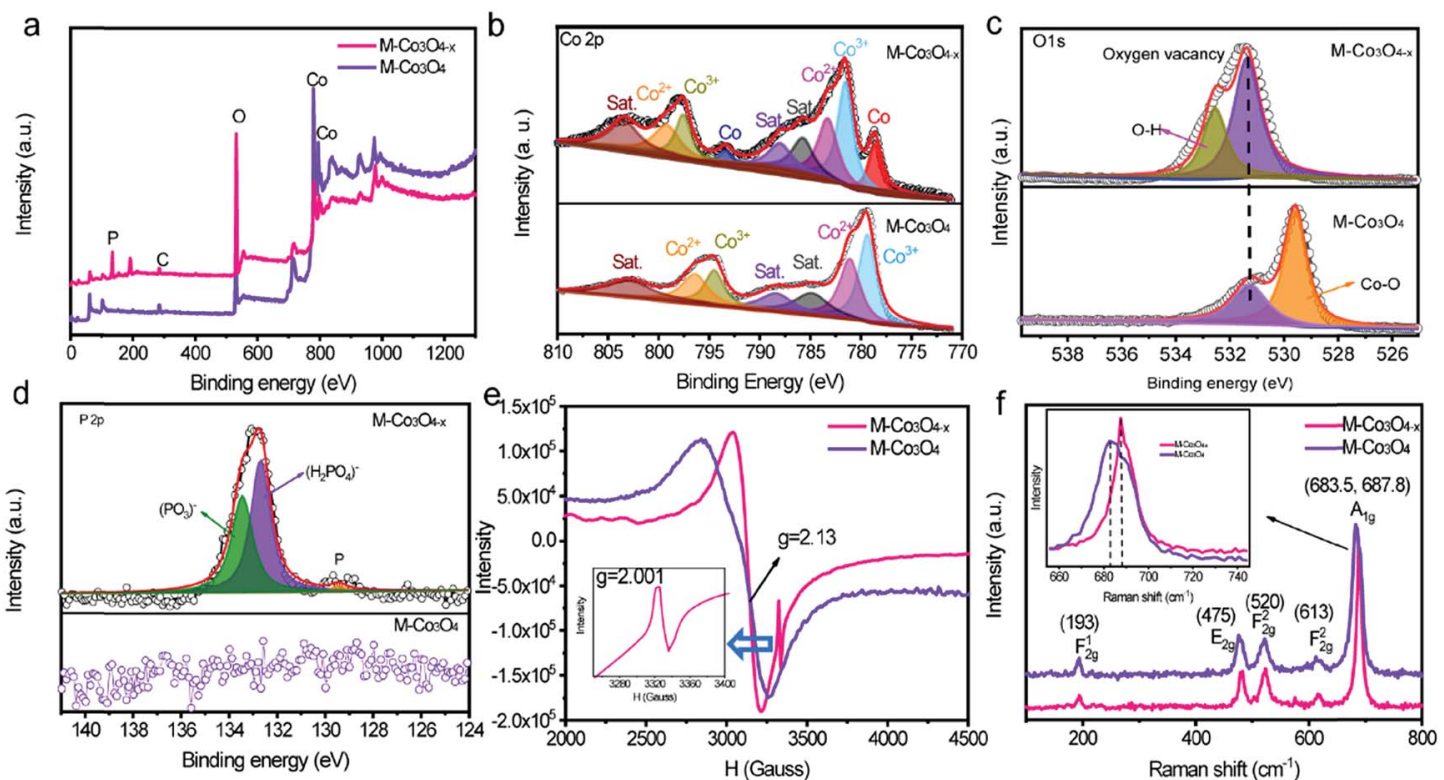

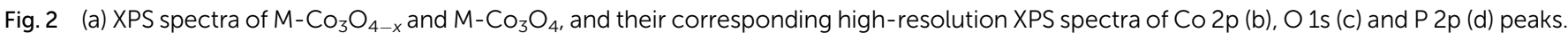
(e) EPR spectra of $\mathrm{M}-\mathrm{CO}_{3} \mathrm{O}_{4-x}$ and $\mathrm{M}-\mathrm{CO}_{3} \mathrm{O}_{4}$ samples. (f) Raman spectra of $\mathrm{M}-\mathrm{CO}_{3} \mathrm{O}_{4-x}$ and $\mathrm{M}-\mathrm{CO}_{3} \mathrm{O}_{4}$ samples. 
(XPS) and low temperature electron paramagnetic resonance (EPR) measurements. The XPS full-survey scan spectra (Fig. 2a) exhibit the characteristic peaks for Co, $\mathrm{O}$ and/or $\mathrm{P}$ as the prin-

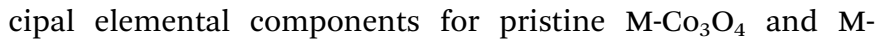
$\mathrm{Co}_{3} \mathrm{O}_{4-x}$. The Co 2p emission spectra of both samples (Fig. 2b) show two spin orbit doublets (Co 2 $\mathrm{p}_{1 / 2}$ and Co 2 $\mathrm{p}_{2 / 3}$ ) and three

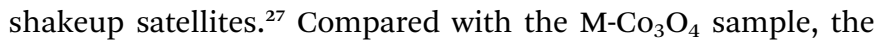
surface $\mathrm{Co}^{2+} / \mathrm{Co}^{3+}$ ratio of the $\mathrm{M}-\mathrm{Co}_{3} \mathrm{O}_{4-x}$ sample is increased from 1.08 to 1.16 , suggesting that some $\mathrm{Co}^{3+}$ species are successfully reduced to $\mathrm{Co}^{2+}$ after the thermal-reduction process. Moreover, the peak of Co $2 p$ shifted to a higher energy location, which further indicates the increased ratio of $\mathrm{Co}^{2+} /$ $\mathrm{Co}^{3+}$ in the surface lattice. ${ }^{28}$ In addition, there are noticeable characteristic peaks of $\mathrm{Co}^{29}$ suggesting the existence of a spot of the metal Co phase in $\mathrm{M}-\mathrm{Co}_{3} \mathrm{O}_{4-x}$. Fig. 2c compares the core level O 1s XPS spectra of the pristine $\mathrm{M}-\mathrm{Co}_{3} \mathrm{O}_{4}$ and $\mathrm{M}-\mathrm{Co}_{3} \mathrm{O}_{4-x}$ samples. The peak at $531.5 \mathrm{eV}$ is ascribed to oxygen vacancy sites with a low oxygen coordination, ${ }^{30}$ and the peak at $532.7 \mathrm{eV}$ belongs to $\mathrm{O}-\mathrm{H}$ from surface absorbed water. ${ }^{30,31}$ In comparison with the pristine $\mathrm{M}-\mathrm{Co}_{3} \mathrm{O}_{4}$ sample, the peak attributed to oxygen vacancy sites $(531.5 \mathrm{eV})$ is obviously enhanced for $\mathrm{M}-\mathrm{Co}_{3} \mathrm{O}_{4-x}$, indicating an increased number of oxygen defects after the thermal-reduction treatment. The $\mathrm{P} 2 \mathrm{p}$ core-level XPS spectra (Fig. 2d) reveal that the $\mathrm{P}$ species present as $\left(\mathrm{PO}_{3}\right)^{-}$and $\left(\mathrm{HPO}_{4}\right)^{2-}$ on the surface of $\mathrm{M}^{-\mathrm{Co}_{3} \mathrm{O}_{4-x}}$ which may also contribute to electrochemical reactivity. ${ }^{32}$ The thermal reduction result is further investigated by using EPR spectra (Fig. 2e). The big signal peak in EPR spectrum is attributed to $\mathrm{Co}^{2+}$ which is noticed higher in $\mathrm{M}-\mathrm{Co}_{3} \mathrm{O}_{4-x}$ than that of pristine $\mathrm{M}-\mathrm{Co}_{3} \mathrm{O}_{4}$, confirming the generation of $\mathrm{Co}^{2+}$ species after the reduction treatment. In addition, a noticeable narrow peak signal with a $g$ factor of 2.001 is developed in the $\mathrm{M}-\mathrm{Co}_{3} \mathrm{O}_{4-x}$ spectrum, which is characteristic of paramagnetic (single-electron-trapped) oxygen vacancies, ${ }^{33}$ verifying the formation of oxygen vacancies in the lattice. Both Raman spectra of $\mathrm{M}-\mathrm{Co}_{3} \mathrm{O}_{4}$ and $\mathrm{M}-\mathrm{Co}_{3} \mathrm{O}_{4-x}$ in Fig. 2f display characteristic peaks at 193, 475, 520, 613 and around $685 \mathrm{~cm}^{-1}$, corresponding to the F12g, E2g, F22g, F22g, and $\mathrm{A} 1 \mathrm{~g}$ phonon modes of the Co-O bond respectively. ${ }^{34}$ In addition, it is worth noting that the $\mathrm{A} 1 \mathrm{~g}$ peak center for the $\mathrm{M}$ $\mathrm{Co}_{3} \mathrm{O}_{4-x}$ sample is obviously blue shifted $\left(687.8 \mathrm{~cm}^{-1}\right)$ compared with that of pristine $\mathrm{M}-\mathrm{Co}_{3} \mathrm{O}_{4}\left(683.5 \mathrm{~cm}^{-1}\right)$, which suggests the change of vibrational energy levels of Co-O after the formation of oxygen vacancies.

To illustrate the virtues of our structure and defect design in boosting the electrochemical performance, non-porous $\mathrm{Co}_{3} \mathrm{O}_{4}$ nanoparticles and non-porous oxygen-vacancy $\mathrm{Co}_{3} \mathrm{O}_{4}$ (denoted as $\mathrm{Co}_{3} \mathrm{O}_{4-x}$ ) nanoparticle products are also prepared via similar synthetic procedures (Experiment section, Fig. S3†). The electrochemical performance of the as-prepared samples as cathodes in aqueous ZBBs is evaluated with metallic $\mathrm{Zn}$ foil as the anode in the electrolyte of $6 \mathrm{M} \mathrm{KOH}$ with $0.02 \mathrm{M} \mathrm{Zn(Ac)})_{2}$. Fig. 3a compares the cyclic voltammetry $(\mathrm{CV})$ profiles of the $\mathrm{M}-\mathrm{Co}_{3} \mathrm{O}_{4} / /$ $\mathrm{Zn}, \mathrm{M}-\mathrm{Co}_{3} \mathrm{O}_{4-x} / / \mathrm{Zn}, \mathrm{Co}_{3} \mathrm{O}_{4} / / \mathrm{Zn}$, and $\mathrm{Co}_{3} \mathrm{O}_{4-x} / / \mathrm{Zn}$ batteries at 10 $\mathrm{mV} \mathrm{s}^{-1}$, from which the highest current densities are observed for the $\mathrm{M}-\mathrm{Co}_{3} \mathrm{O}_{4-x} / / \mathrm{Zn}$ battery. This demonstrates the significantly enhanced electrochemical performance of the $\mathrm{M}$ $\mathrm{Co}_{3} \mathrm{O}_{4-x}$ electrode after introducing $3 \mathrm{D}$ ordered mesopores and oxygen vacancies. The redox peaks in the four $\mathrm{CV}$ curves are attributed to reversible faradaic processes between $\mathrm{Co}-\mathrm{O}$ and $\mathrm{CoO}-\mathrm{OH}$ in the alkaline electrolyte. ${ }^{7,27}$
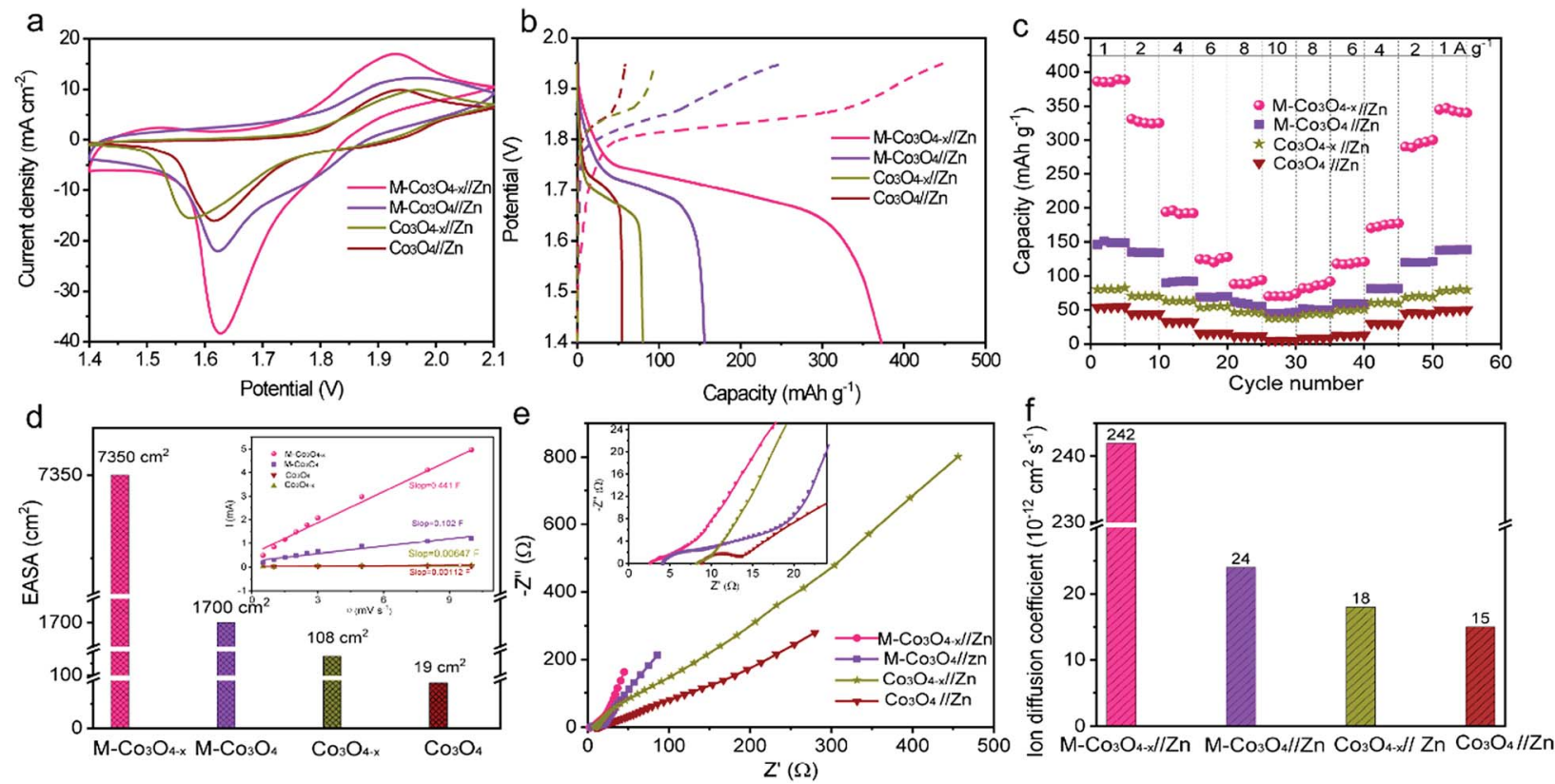

Fig. 3 (a and b) CV and GCD curves of $\mathrm{M}-\mathrm{CO}_{3} \mathrm{O}_{4-x} / / \mathrm{Zn}, \mathrm{M}-\mathrm{CO}_{3} \mathrm{O}_{4} / / \mathrm{Zn}, \mathrm{CO}_{3} \mathrm{O}_{4-x} / / \mathrm{Zn}$ and $\mathrm{CO}_{3} \mathrm{O}_{4} / / \mathrm{Zn}$ batteries at $10 \mathrm{mV} \mathrm{s}^{-1}$ and $1 \mathrm{~A} \mathrm{~g}^{-1}$, respectively. (c) Rate performance of the batteries at various current densities. (d, e and f) Electrochemically active surface area (EASA), electrochemical impedance spectroscopy (EIS) and ion diffusion coefficient (D) tests of $\mathrm{M}-\mathrm{Co}_{3} \mathrm{O}_{4-x} / / \mathrm{Zn}, \mathrm{M}-\mathrm{CO}_{3} \mathrm{O}_{4} / / \mathrm{Zn}, \mathrm{CO}_{3} \mathrm{O}_{4-x} / / \mathrm{Zn}$ and $\mathrm{CO}_{3} \mathrm{O}_{4} / / \mathrm{Zn}$ batteries. 
The galvanostatic charge-discharge (GCD) profiles of $\mathrm{M}$ $\mathrm{Co}_{3} \mathrm{O}_{4-x} / / \mathrm{Zn}, \quad \mathrm{M}-\mathrm{Co}_{3} \mathrm{O}_{4} / / \mathrm{Zn}, \quad \mathrm{Co}_{3} \mathrm{O}_{4-x} / / \mathrm{Zn}$ and $\mathrm{Co}_{3} \mathrm{O}_{4} / /$ $\mathrm{Zn}$ batteries are displayed in Fig. 3b. Obviously, the $\mathrm{M}^{-\mathrm{Co}_{3}} \mathrm{O}_{4-x} / /$ Zn battery delivers a considerably longer discharge plateau than the other three batteries, confirming its highest capacity. By calculation, the $\mathrm{Zn} / / \mathrm{M}-\mathrm{Co}_{3} \mathrm{O}_{4-x}$ yields a remarkable specific capacity of $384 \mathrm{~mA} \mathrm{~h} \mathrm{~g}{ }^{-1}$ (based on the weights of $\mathrm{M}^{-} \mathrm{Co}_{3} \mathrm{O}_{4-x}$, $0.384 \mathrm{~mA} \mathrm{~h} \mathrm{~cm}^{-2}$ ) at a current density of $1.0 \mathrm{~A} \mathrm{~g}^{-1}$, which is 2.6fold, 4.9-fold and 7.2-fold greater than that of $\mathrm{M}^{-}-\mathrm{CO}_{3} \mathrm{O}_{4}(150 \mathrm{~mA}$ $\left.\mathrm{h} \mathrm{g}^{-1}\right), \mathrm{Co}_{3} \mathrm{O}_{4-x}\left(80 \mathrm{~mA} \mathrm{~h} \mathrm{~g}{ }^{-1}\right)$ and $\mathrm{Co}_{3} \mathrm{O}_{4}\left(50 \mathrm{~mA} \mathrm{~h} \mathrm{~g}{ }^{-1}\right)$, respectively. The above results indicate a strong synergistic effect between the porous architecture and oxygen vacancies on electrochemical energy storage and highlight the superiority of the optimized $\mathrm{M}-\mathrm{Co}_{3} \mathrm{O}_{4-x}$ nanoarray as a cathode electrode. In addition, the high specific capacity of the $\mathrm{M}^{-} \mathrm{Co}_{3} \mathrm{O}_{4-x} / / \mathrm{Zn}$ battery is the highest value among those of all the cathode materials for $\mathrm{Zn}$-based batteries so far (except $\mathrm{Zn}$-Air batteries) (Table S2 $\dagger$ ), such as $\mathrm{Zn} / / \mathrm{V}_{2} \mathrm{O}_{5}\left(224 \mathrm{~mA} \mathrm{~h} \mathrm{~g}{ }^{-1}\right.$ at $\left.0.1 \mathrm{~A} \mathrm{~g}^{-1}\right),{ }^{12} \mathrm{Zn} / /$ $\mathrm{Co}_{3} \mathrm{O}_{4}\left(168 \mathrm{~mA} \mathrm{~h} \mathrm{~g}^{-1}\right.$ at $\left.1 \mathrm{~A} \mathrm{~g}^{-1}\right),{ }^{7} \alpha-\mathrm{MnO}_{2} / / \mathrm{Zn}\left(382.2 \mathrm{~mA} \mathrm{~h} \mathrm{~g}^{-1}\right.$ at $\left.0.3 \mathrm{~A} \mathrm{~g}^{-1}\right),{ }^{35} \mathrm{ZnMn}_{2} \mathrm{O}_{4} / / \mathrm{Zn}\left(150 \mathrm{~mA} \mathrm{~h} \mathrm{~g}{ }^{-1}\right.$ at $\left.0.5 \mathrm{~A} \mathrm{~g}^{-1}\right),{ }^{36} \mathrm{VS}_{2} / /$ $\mathrm{Zn}\left(190.3 \mathrm{~mA} \mathrm{~h} \mathrm{~g}{ }^{-1}\right.$ at $\left.0.05 \mathrm{~A} \mathrm{~g}^{-1}\right),{ }^{37} \mathrm{Zn} /$ polyaniline (PANI)intercalated $\mathrm{MnO}_{2}\left(280 \mathrm{~mA} \mathrm{~h} \mathrm{~g}{ }^{-1}\right.$ at $\left.0.2 \mathrm{~A} \mathrm{~g}^{-1}\right),{ }^{38} \mathrm{Na}_{1.1} \mathrm{~V}_{3^{-}}$ $\mathrm{O}_{7.9} @ \mathrm{rGO} / / \mathrm{Zn}\left(220 \mathrm{~mA} \mathrm{~h}{ }^{-1}\right.$ at $\left.0.3 \mathrm{~A} \mathrm{~g}^{-1}\right),{ }^{39} \mathrm{Zn} / / \mathrm{Na}_{0.95} \mathrm{MnO}_{2}(60$ $\mathrm{mA} \mathrm{h} \mathrm{g}^{-1}$ at $\left.2 \mathrm{C}\right){ }^{40}$ and $\mathrm{Zn} / / \mathrm{Al}$ ion batteries $\left(94 \mathrm{~mA} \mathrm{~h} \mathrm{~g}^{-1}\right.$ at $0.1 \mathrm{~A}$ $\left.\mathrm{g}^{-1}\right){ }^{41}$ Meanwhile, the area capacity of our $\mathrm{Zn} / / \mathrm{M}-\mathrm{Co}_{3} \mathrm{O}_{4-x}$ battery $\left(0.384 \mathrm{~mA} \mathrm{~h} \mathrm{~cm}^{-2}\right)$ is also higher than or comparable to that of reported ZBBs with a similar mass loading (based on cathode materials), such as $\mathrm{Zn} / / \mathrm{Co}_{3} \mathrm{O}_{4}\left(0.336 \mathrm{~mA} \mathrm{~h} \mathrm{~cm}^{-2}\right.$ at 2 $\left.\mathrm{mA} \mathrm{cm}{ }^{-2}\right),{ }^{7} \mathrm{Zn} / / \mathrm{ZnMn}_{2} \mathrm{O}_{4}\left(0.3 \mathrm{~mA} \mathrm{~h} \mathrm{~cm}{ }^{-2}\right.$ at $\left.0.1 \mathrm{~mA} \mathrm{~cm}{ }^{-2}\right),{ }^{36}$ NiAlCoLDH//Zn $\left(0.305 \mathrm{~mA} \mathrm{~h} \mathrm{~cm}{ }^{-2}\right.$ at $\left.5.81 \mathrm{~mA} \mathrm{~cm}^{-2}\right),{ }^{42}$ and $\mathrm{Zn} /$ $\mathrm{Co}$ (III) rich- $\mathrm{CO}_{3} \mathrm{O}_{4}$ batteries $\left(0.215 \mathrm{~mA} \mathrm{~h} \mathrm{~cm}{ }^{-2}\right.$ at $0.525 \mathrm{~mA}$ $\left.\mathrm{cm}^{-2}\right) \cdot{ }^{10}$

The detailed rate performance of the four batteries is presented in Fig. $3 \mathrm{c}$ and S4a. $\uparrow$ When cycling at current densities of $1,2,4,6,8$ and $10 \mathrm{~A} \mathrm{~g}^{-1}$, the $\mathrm{M}-\mathrm{Co}_{3} \mathrm{O}_{4-x} / / \mathrm{Zn}$ battery exhibits capacities of $384,331,196,125,92$ and $70 \mathrm{~mA} \mathrm{~h} \mathrm{~g}{ }^{-1}$, respectively, and these values are much higher than those of the M$\mathrm{Co}_{3} \mathrm{O}_{4} / / \mathrm{Zn}, \mathrm{Co}_{3} \mathrm{O}_{4-x} / / \mathrm{Zn}$ and $\mathrm{Co}_{3} \mathrm{O}_{4} / / \mathrm{Zn}$ batteries. Upon switching back to $1.0 \mathrm{~A} \mathrm{~g}^{-1}$ after 50 cycles, the specific capacity of the $\mathrm{M}-\mathrm{Co}_{3} \mathrm{O}_{4-x} / / \mathrm{Zn}$ battery still remains at $340 \mathrm{~mA} \mathrm{~h} \mathrm{~g}{ }^{-1}$, revealing its outstanding capacity and cycling performance. All these observations suggest a great enhancement of the electrochemical performance of the $\mathrm{M}-\mathrm{Co}_{3} \mathrm{O}_{4-x} / / \mathrm{Zn}$ battery over the others.

To investigate the electrochemical kinetics of the $\mathrm{M}$ $\mathrm{Co}_{3} \mathrm{O}_{4-x} / / \mathrm{Zn}$ battery, the anodic/cathodic current $(i)$ is assumed to obey a power-law relationship with the scan rate $(v)$ of $i=a v^{b}$, with $a$ and $b$ being adjustable values. In the $\ln (i)-\ln (\nu)$ plot (Fig. $\mathrm{S} 4 \mathrm{~b} \dagger$ ), the $\mathrm{M}-\mathrm{Co}_{3} \mathrm{O}_{4-x} / / \mathrm{Zn}$ battery possesses an approximate $b$-value of 0.5 at scan rates ranging from 5 to $100 \mathrm{mV} \mathrm{s}^{-1}$, implying a diffusion-controlled kinetics process. Such improved performance is clearly elucidated by electrochemically active surface area (EASA), electrochemical impedance spectroscopy (EIS) and ion diffusion coefficient $(D)$ tests. The EASA of these samples is estimated using a mature method as seen in the ESI $\dagger$ calculation, ${ }^{31,43}$ and Fig. S5. $\uparrow$ The Fig. $3 \mathrm{~d}$ inset displays the anodic charging current $(i)$ measured at $1.45 \mathrm{~V}$ as a function of the scan rate for all electrodes. Importantly, $\mathrm{M}_{-} \mathrm{Co}_{3} \mathrm{O}_{4-x}$ achieves a far steeper slope than the $\mathrm{M}-\mathrm{Co}_{3} \mathrm{O}_{4}, \mathrm{Co}_{3} \mathrm{O}_{4-x}$ and $\mathrm{Co}_{3} \mathrm{O}_{4}$ samples, revealing its largest number of active sites. The corresponding EASA of the $\mathrm{M}_{-}-\mathrm{Co}_{3} \mathrm{O}_{4-x}$ electrode, determined by assuming a $\mathrm{C}_{\mathrm{dl}}$ value of $60 \mu \mathrm{F} \mathrm{cm} \mathrm{cm}^{-2}$ for a smooth surface sample, ${ }^{31,43}$ is $7350 \mathrm{~cm}^{2}$, which is much higher than that of M$\mathrm{Co}_{3} \mathrm{O}_{4}\left(1700 \mathrm{~cm}^{2}\right), \mathrm{Co}_{3} \mathrm{O}_{4-x}\left(108 \mathrm{~cm}^{2}\right)$ and $\mathrm{Co}_{3} \mathrm{O}_{4}\left(19 \mathrm{~cm}^{2}\right)$. Obviously, the mesoporous and/or defective oxygen-vacancy samples show a much higher EASA than pristine ones, indicating the crucial synergetic effect of the mesopores and oxygen vacancies. The charge transfer resistance $\left(R_{\mathrm{ct}}\right.$, the diameter of semicircles on the $x$-axis of the Nyquist plot, Fig. 3e) of $\mathrm{M}$ $\mathrm{Co}_{3} \mathrm{O}_{4-x} / / \mathrm{Zn}$ and $\mathrm{Co}_{3} \mathrm{O}_{4-x} / / \mathrm{Zn}$ batteries is determined to be 2.0 $\Omega$ and $1.4 \Omega$, respectively, which are much smaller than those of $\mathrm{M}-\mathrm{Co}_{3} \mathrm{O}_{4} / / \mathrm{Zn}(4.4 \Omega)$ and $\mathrm{Co}_{3} \mathrm{O}_{4} / / \mathrm{Zn}(5.0 \Omega)$. The smaller resistance confirms that oxygen vacancies are able to greatly improve the conductivity of cobaltosic oxide, which is consistent with most previous reports. ${ }^{23,44,45}$ In addition, in the low frequency region, $\mathrm{M}-\mathrm{Co}_{3} \mathrm{O}_{4-x} / / \mathrm{Zn}$ exhibits a steeper slope than the other three batteries, implying that the ion mobility in $\mathrm{M}_{-}-\mathrm{Co}_{3} \mathrm{O}_{4-x}$ is very efficient. To quantify the ion diffusion rate in the electrodes, we further measured the chemical diffusion coefficient (D) by using the potentiostatic intermittent titration technique (PITT) ${ }^{46}$ Fig. S6a $\dagger$ shows the transient $i-t$ plots of the M$\mathrm{Co}_{3} \mathrm{O}_{4-x} / / \mathrm{Zn}, \quad \mathrm{M}-\mathrm{Co}_{3} \mathrm{O}_{4} / / \mathrm{Zn}, \quad \mathrm{Co}_{3} \mathrm{O}_{4-x} / / \mathrm{Zn}$ and $\mathrm{Co}_{3} \mathrm{O}_{4} / / \mathrm{Zn}$ batteries collected at $1.72 \mathrm{~V}$ with a potential step of $10 \mathrm{mV}$. The rate of current decay is related to the speed of ion diffusion from the electrode/electrolyte interface into the electrode. The $\ln (i)-t$ curves are collected and are linearly fitted (Fig. S6b $\dagger$ ), and the value of $D$ is calculated from the slope of the linear region in the plot of $\ln (i)$ vs. $t$ (ESI, $\dagger$ "calculation"), using the following equation:

$$
D=-\frac{\mathrm{d} \ln (i)}{\mathrm{d} t} \frac{4 L^{2}}{\pi}
$$

Significantly, the $\mathrm{M}-\mathrm{Co}_{3} \mathrm{O}_{4-x} / / \mathrm{Zn}$ battery has much higher $D$ values than $\mathrm{M}-\mathrm{Co}_{3} \mathrm{O}_{4} / / \mathrm{Zn}, \mathrm{Co}_{3} \mathrm{O}_{4-x} / / \mathrm{Zn}$ and $\mathrm{Co}_{3} \mathrm{O}_{4} / / \mathrm{Zn}$ electrodes at the potential we measured (Fig. 3f), supporting that the $3 \mathrm{D}$ porous nanoarray and oxygen-vacancy structure enhances the ion diffusion efficiency in the $\mathrm{M}^{-\mathrm{Co}_{3} \mathrm{O}_{4-x}}$ electrode.

The density functional theory (DFT) calculations are carried out to investigate the effect of oxygen vacancies of $\mathrm{M}^{-} \mathrm{Co}_{3} \mathrm{O}_{4-x}$ on its electrochemical performance. The total densities of states

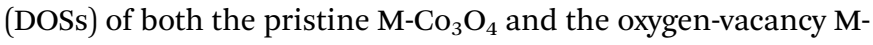
$\mathrm{Co}_{3} \mathrm{O}_{4-x}$ are plotted in Fig. 4a. Obviously, for the oxygen-vacancy $\mathrm{M}-\mathrm{Co}_{3} \mathrm{O}_{4-x}$ a new state is formed within the band gap, located at $\approx 1.5 \mathrm{eV}$ below the conduction band minimum, which narrows the bandgap of the valence and conduction bands from 2.7 to $0.89 \mathrm{eV}$. This narrowed bandgap is beneficial for the enhanced excitation of charge carriers to the conduction band, which accounts for the experimentally observed increasing conductivity after the formation of oxygen vacancies in $\mathrm{Co}_{3} \mathrm{O}_{4}$. Meanwhile, the charge distribution in $\mathrm{M}-\mathrm{Co}_{3} \mathrm{O}_{4-x}$ is disturbed after the incorporation of oxygen vacancies. As shown in Fig. $4 \mathrm{~b}$, the charge densities around oxygen vacancies are weakened, and this special charge distribution can provide more active sites for 

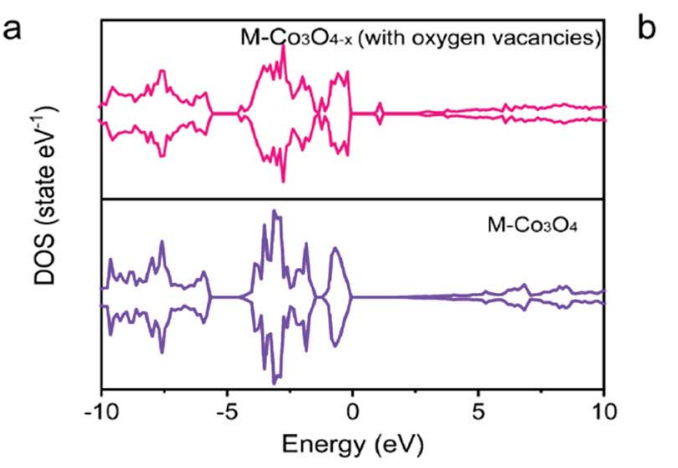

C

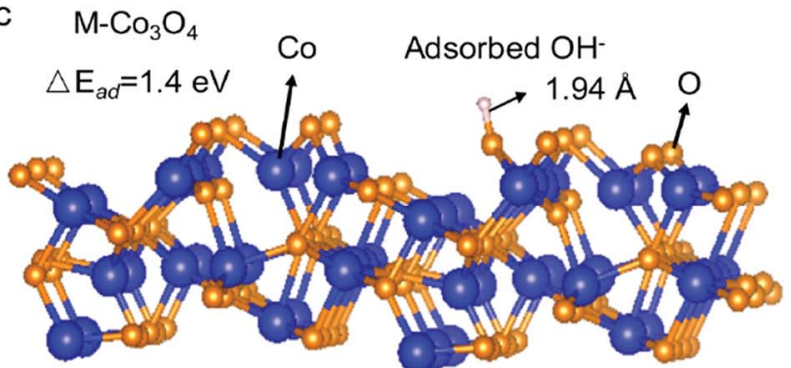

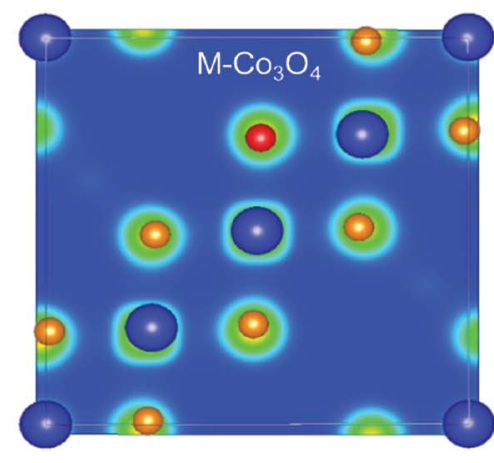
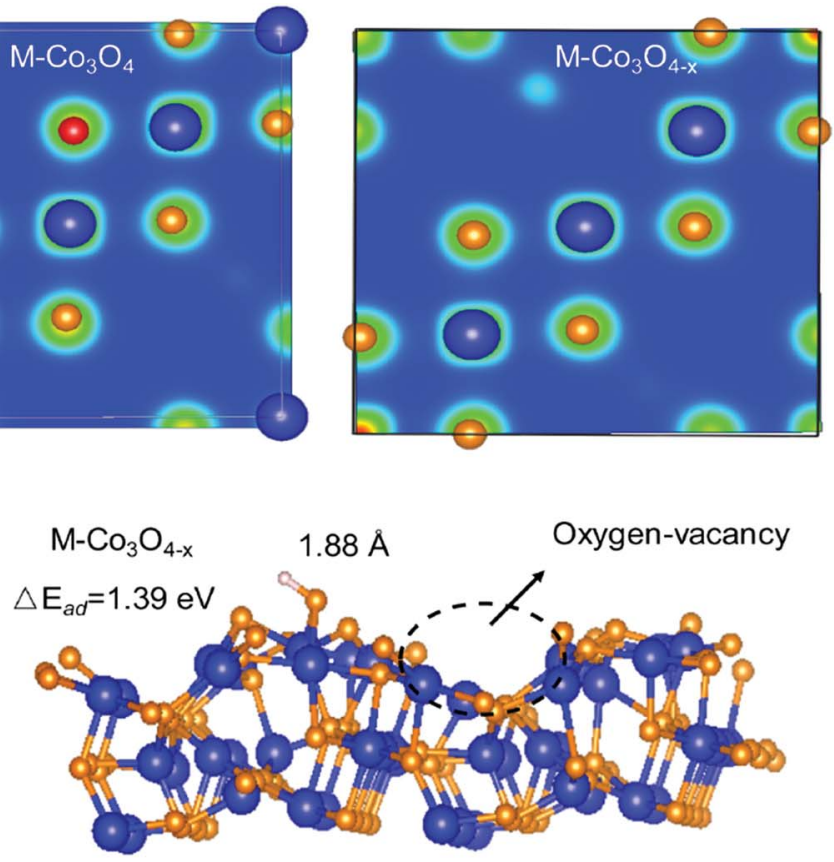

Fig. 4 (a) DOS of pristine $\mathrm{M}-\mathrm{CO}_{3} \mathrm{O}_{4}$ and defective $\mathrm{M}-\mathrm{CO}_{3} \mathrm{O}_{4-x}$ (with oxygen vacancies). (b) The differential charge density of $\mathrm{M}-\mathrm{CO}_{3} \mathrm{O}_{4}$ and $\mathrm{M}-$ $\mathrm{CO}_{3} \mathrm{O}_{4-x}$. (c) Calculated structures and $\mathrm{OH}^{-}$adsorption energies $\left(\Delta E_{\mathrm{ad}}\right)$ of $\mathrm{M}-\mathrm{CO}_{3} \mathrm{O}_{4}$ (311) and $\mathrm{M}-\mathrm{CO}_{3} \mathrm{O}_{4-x}$ (with oxygen vacancies) (311) surfaces.

electrochemical reactions. ${ }^{20}$ In addition, the energy storage nature is gained by assessing the adsorption properties of $\mathrm{OH}^{-}$ on the surface of cobaltosic oxide, and two configurations of $\mathrm{M}$ $\mathrm{Co}_{3} \mathrm{O}_{4}$ (311) and oxygen-vacancy $\mathrm{M}-\mathrm{Co}_{3} \mathrm{O}_{4-x}$ (311) are modeled in Fig. 4c. Compared with pristine $\mathrm{M}-\mathrm{Co}_{3} \mathrm{O}_{4}$ (Fig. 4c), the oxygen-vacancy $\mathrm{M}-\mathrm{Co}_{3} \mathrm{O}_{4-x}$ shows smaller calculated absorption energy $\left(\Delta E_{\mathrm{ad}}\right)$ and a decreased Co-O bond length of adsorbed $\mathrm{OH}^{-}$by $0.01 \mathrm{eV}$ and $0.06 \AA$, respectively, indicating its stronger affinity with $\mathrm{OH}^{-}$after introducing oxygen vacancies, which is useful to accelerate the following faradaic reaction for energy storage: $\mathrm{CoOOH}+\mathrm{OH}^{-} \rightleftharpoons \mathrm{CoO}_{2}+\mathrm{H}_{2} \mathrm{O}+\mathrm{e}^{-}$. The theoretical calculations support that the oxygen vacancies could endow $\mathrm{Co}_{3} \mathrm{O}_{4}$ with an optimal electronic structure for energy storage.

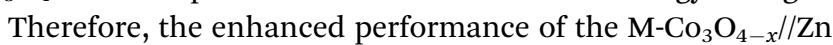
battery can be attributed to the unique features of its $\mathrm{M}-\mathrm{Co}_{3} \mathrm{O}_{4-x}$ cathode. First, the 3D ordered mesoporous nanoarray structure simultaneously provides higher electron-ion transport pathways and more electrochemical active area, which is much higher than that of its bulk counterparts. Second, the introduction of oxygen vacancies into the nanoarray decreases the energy required for the adsorption of $\mathrm{OH}^{-}$onto the surface, which in turn leads to an enhanced redox reaction. Finally, the defect feature improves the electrode's electrical conductivity and shortens the electron transfer distance from the redox sites to the conductive intermediate via metallic Co-Co chains and oxygen vacancies resulting in facilitating charge transfer kinetics.

We also investigated the influence of the calcination temperature on the electrochemical properties of the $\mathrm{M}-\mathrm{Co}_{3} \mathrm{O}_{4}$ electrode. The samples of $\mathrm{M}-\mathrm{Co}_{3} \mathrm{O}_{4}$ treated at different phos-

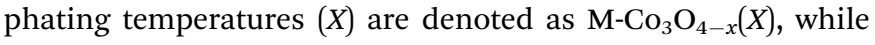

the sample treated at $250{ }^{\circ} \mathrm{C}$ is denoted as $\mathrm{M}-\mathrm{Co}_{3} \mathrm{O}_{4-x}$ in the text. These oxygen-defective $\mathrm{M}-\mathrm{Co}_{3} \mathrm{O}_{4-x}(X)$ samples are characterized and tested as shown in Fig. S7-S13. $\dagger$ As the thermal treatment temperature increases from $205{ }^{\circ} \mathrm{C}$ to $300{ }^{\circ} \mathrm{C}$, these samples give similar morphologies, but a rougher surface, lower BET surface area, larger pore size and more oxygen vacancies and $\mathrm{Co} / \mathrm{CoO}$ phase formation accompanied by more $\mathrm{Co}^{3+}$ species reduction (Fig. S7, S8a, S8b, S8c, S8d and S10†). Fig. $\mathrm{S} 12 \mathrm{a}$ and $\mathrm{S} 12 \mathrm{~b} \dagger$ compare the capacities of the pristine $\mathrm{M}$ $\mathrm{Co}_{3} \mathrm{O}_{4}$ and $\mathrm{M}-\mathrm{Co}_{3} \mathrm{O}_{4-x}(X)$ electrodes at $1 \mathrm{~A} \mathrm{~g}^{-1}$ current density. Evidently, all $\mathrm{M}-\mathrm{Co}_{3} \mathrm{O}_{4-x}(X) / / \mathrm{Zn}$ exhibit higher capacity than pristine $\mathrm{M}-\mathrm{Co}_{3} \mathrm{O}_{4} / / \mathrm{Zn}$, revealing that structural defects exert a profound effect on the charge-discharge properties of the $\mathrm{M}$ $\mathrm{Co}_{3} \mathrm{O}_{4}$ electrode. But excess oxygen vacancies lead to the

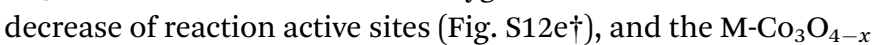
electrode with $250{ }^{\circ} \mathrm{C} \mathrm{NaH} \mathrm{NO}_{2} \cdot \mathrm{H}_{2} \mathrm{O}$ treatment shows the best performance.

We also studied the long-term cycling performance of the M$\mathrm{Co}_{3} \mathrm{O}_{4-x} / / \mathrm{Zn}$ battery. Fig. 5a shows the variation of the specific capacity collected for the four batteries at a current density of 10 $\mathrm{A} \mathrm{g}^{-1}$ for 20000 and/or 60000 cycles. Notably, the specific capacity of the $\mathrm{M}-\mathrm{Co}_{3} \mathrm{O}_{4-x} / / \mathrm{Zn}$ battery continuously increases in the initial 20000 cycles and then remains comparatively steady as the cycling continued. After 60000 cycles, the $\mathrm{M}-\mathrm{Co}_{3} \mathrm{O}_{4-x} / / \mathrm{Zn}$ battery achieves $140 \mathrm{~mA} \mathrm{~h} \mathrm{~g}^{-1}$, which represents an about $400 \%$ enhancement compared with its initial capacity before cycling (35 $\mathrm{mA} \mathrm{h} \mathrm{g}^{-1}$ ). The capacity increases up to $120 \%$ (after 2000 cycles) compared to the first cycle and remains stable even after 6000 cycles under deep charge-discharge conditions of $1 \mathrm{~A} \mathrm{~g}^{-1}$, (Fig. S14 $\dagger$ ), indicating an ultrahigh cycling ability and structural stability. In contrast, the $\mathrm{M}-\mathrm{Co}_{3} \mathrm{O}_{4} / / \mathrm{Zn}, \mathrm{Co}_{3} \mathrm{O}_{4-x} / / \mathrm{Zn}$ and $\mathrm{Co}_{3} \mathrm{O}_{4} / /$ 

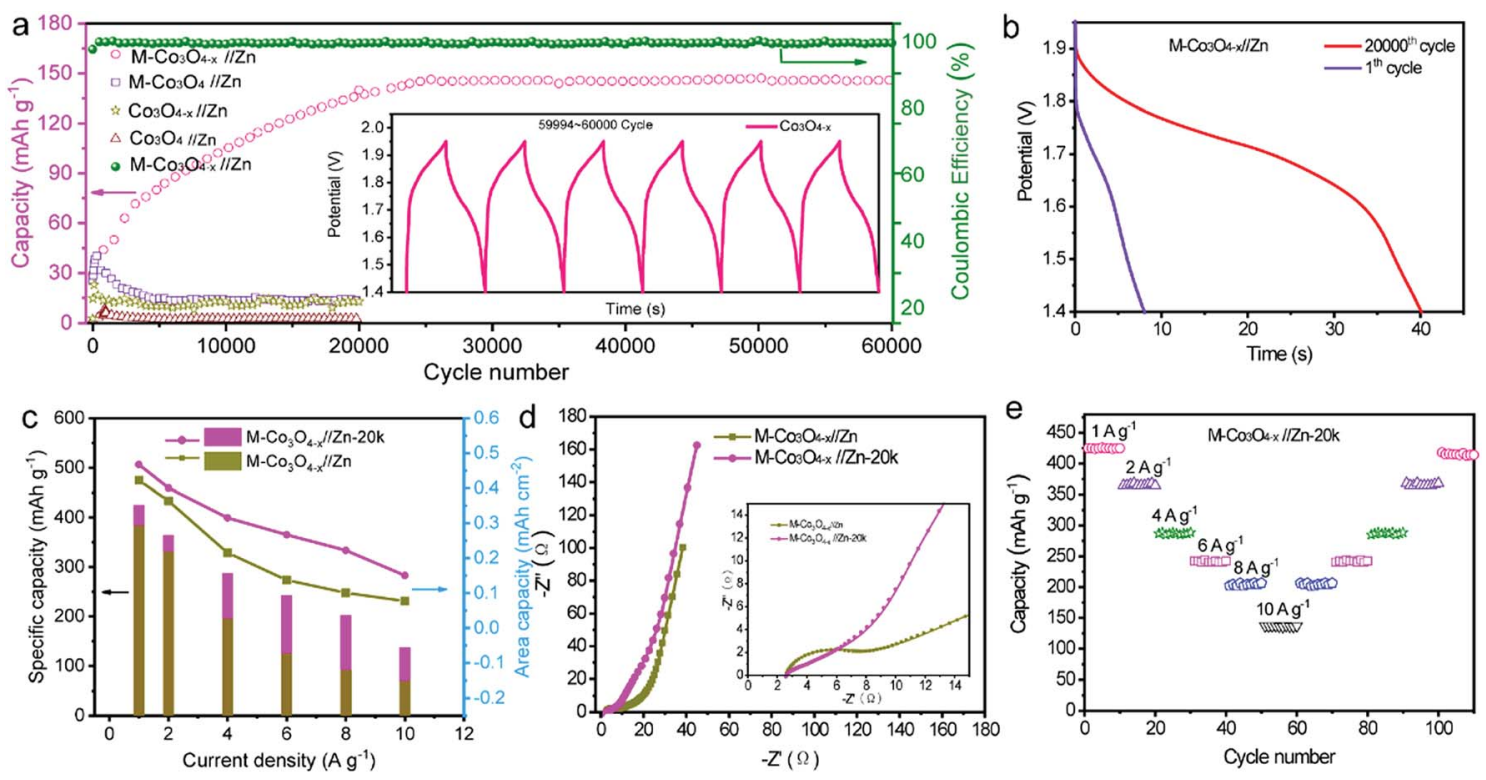

Fig. 5 (a) Cycling performance of $\mathrm{M}-\mathrm{CO}_{3} \mathrm{O}_{4-x} / / \mathrm{Zn}, \mathrm{M}-\mathrm{CO}_{3} \mathrm{O}_{4} / / \mathrm{Zn}, \mathrm{CO}_{3} \mathrm{O}_{4-x} / / \mathrm{Zn}$ and $\mathrm{Co}_{3} \mathrm{O}_{4-x} / / \mathrm{Zn}$ batteries at $10 \mathrm{~A} \mathrm{~g}{ }^{-1}$. (b, c and d) GCD curves, specific capacities at various current densities and Nyquist plots of $\mathrm{M}-\mathrm{CO}_{3} \mathrm{O}_{4-x} / / \mathrm{Zn}$ and $\mathrm{M}-\mathrm{CO}_{3} \mathrm{O}_{4-x} / / \mathrm{Zn}-2 \mathrm{OK}$ batteries. (e) Cycling rate performance of $\mathrm{M}-\mathrm{CO}_{3} \mathrm{O}_{4-x} / / \mathrm{Zn}-2 \mathrm{OK}$.

Zn batteries show much lower cycling abilities and capacities. To the best of our knowledge, such a long cycling lifespan has not been reported in ZBBs to date. Considering that the $\mathrm{Zn}$ anode has great influence on the stability of Zn-based batteries, the morphology and phase of the $\mathrm{Zn}$ anode after cycling were investigated. As shown in Fig. S15 and S16, $\uparrow$ the smooth surface of the $\mathrm{Zn}$ anode became highly coarse and some $\mathrm{ZnO}$ was formed on its surface. However, the $\mathrm{Zn}$ anode used in our experiment is highly overdosed (the mass ratio of $\mathrm{Zn}$ to $\mathrm{Co}_{3} \mathrm{O}_{4}$ is up to $170: 1$ ), and the effect of the dendrite issue of the $\mathrm{Zn}$ anode on the stability of these four batteries is not dominant. The electrochemical performance of the $\mathrm{M}-\mathrm{Co}_{3} \mathrm{O}_{4-x}$ electrode after 20000 cycles is further investigated, and good capacitive behavior is maintained. Fig. 5b, $\mathrm{c}$ and $\mathrm{d}$ compare the GCD curves, specific capacities at different current densities and EIS for the $\mathrm{M}-\mathrm{Co}_{3} \mathrm{O}_{4-x} / / \mathrm{Zn}$ battery before and after 20000 cycles. The battery after 20000 cycles is denoted as $\mathrm{M}-\mathrm{Co}_{3} \mathrm{O}_{4-x} / / \mathrm{Zn}-20 \mathrm{k}$. Obviously, $\mathrm{M}-\mathrm{Co}_{3} \mathrm{O}_{4-x} / / \mathrm{Zn}-20 \mathrm{k}$ shows higher capacity and rate capacity and lower resistance than that before cycling. When cycling at current densities of $1,2,4,6,8$ and $10 \mathrm{~A} \mathrm{~g}^{-1}, \mathrm{M}$ $\mathrm{Co}_{3} \mathrm{O}_{4-x} / / \mathrm{Zn}-20 \mathrm{k}$ exhibits high capacities of $420 \mathrm{~mA} \mathrm{~h} \mathrm{~g}{ }^{-1}, 366$ $\mathrm{mA} \mathrm{h} \mathrm{g}{ }^{-1}, 288,242,204$, and $137 \mathrm{~mA} \mathrm{~h} \mathrm{~g}^{-1}$, respectively. Upon switching back to $1 \mathrm{~A} \mathrm{~g}^{-1}$ after 110 cycles, the specific capacity is still maintained at $410 \mathrm{~mA} \mathrm{~h} \mathrm{~g}^{-1}$, revealing its outstanding rate and cycling performance (Fig. 5e). Fig. S17† compares the $\mathrm{CV}$

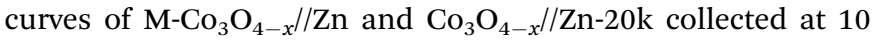
$\mathrm{mV} \mathrm{s}^{-1}$. In addition to the increased current density of $\mathrm{Co}_{3} \mathrm{O}_{4-x} / / \mathrm{Zn}-20 \mathrm{k}$, the intensity of the redox peaks also obviously increased, which may be attributed to the further enrichment of the active material during the cycling test.

To understand the origin of the enhanced capacity and super-long cycle lifespan of the $\mathrm{M}-\mathrm{Co}_{3} \mathrm{O}_{4-x} / / \mathrm{Zn}$ battery, the morphology and chemical composition of the $\mathrm{M}-\mathrm{Co}_{3} \mathrm{O}_{4-x}$ electrode after cycling are investigated. SEM and TEM images reveal that after cycling $\mathrm{M}-\mathrm{Co}_{3} \mathrm{O}_{4-x}$ still kept the ordered porous morphology, which is almost the same as that of the initial M$\mathrm{Co}_{3} \mathrm{O}_{4-x}$ (Fig. S18a, $\uparrow$ S19a). For comparison, the morphologies of $\mathrm{M}-\mathrm{Co}_{3} \mathrm{O}_{4}, \mathrm{Co}_{3} \mathrm{O}_{4-x}$ and $\mathrm{Co}_{3} \mathrm{O}_{4}$ before and after cycling are also determined. The same as $\mathrm{M}-\mathrm{Co}_{3} \mathrm{O}_{4-x}$, pristine $\mathrm{M}^{-\mathrm{Co}_{3} \mathrm{O}_{4}}$ still kept structural stability after cycling (Fig. S18b and $\mathrm{S} 19 \mathrm{~b} \dagger$ ). In contrast, the structures of non-porous $\mathrm{Co}_{3} \mathrm{O}_{4-x}$ and $\mathrm{Co}_{3} \mathrm{O}_{4}$ electrodes are almost totally destroyed (Fig. S18c, S19c and S19d $\dagger$ ), indicating that the ordered $3 \mathrm{D}$ porous structure is useful to keep the structural integrity during the charge/ discharge process. Besides, the EDS mapping of the $\mathrm{M}-\mathrm{Co}_{3} \mathrm{O}_{4-x}$ electrode after cycling (Fig. S20a $\dagger$ ) demonstrates that all elements involved, i.e. Co, O, P, K, and $\mathrm{Zn}$, are homogeneously distributed without enrichment. Fig. S20 $\dagger$ compares the core level Co 2p, O 1s and P 2p XPS spectra of $\mathrm{M}-\mathrm{Co}_{3} \mathrm{O}_{4}$ in different cycles. The ratio of $\mathrm{Co}^{2+} / \mathrm{Co}^{3+}$ decreases and the Co peaks absolutely disappear after cycling, indicating that partial Co and CoO have been re-oxidized during the cycling process, accompanied by the gradual decrease of oxygen vacancies. It is well known that the appropriate amount of the oxygen vacancies is important for achieving optimum electrical conductivity and electrochemical activity. ${ }^{47,48}$ Additionally, oxygen vacancies still exist and remain stable without further decrease after cycling (Fig. S20†). Therefore, the enhanced performance of the M$\mathrm{Co}_{3} \mathrm{O}_{4-x} / / \mathrm{Zn}$ battery during the cycling test is mainly because of the continual formation of electrochemically active $\mathrm{Co}_{3} \mathrm{O}_{4}$ from the oxidization of newly exposed $\mathrm{Co}$ and $\mathrm{CoO}$ and an optimal oxygen-vacancy level achieved during both the activation and cycling test processes. These findings indicate that the electrochemical performance of the $\mathrm{M}-\mathrm{Co}_{3} \mathrm{O}_{4-x}$ electrode can be improved through this activation. 


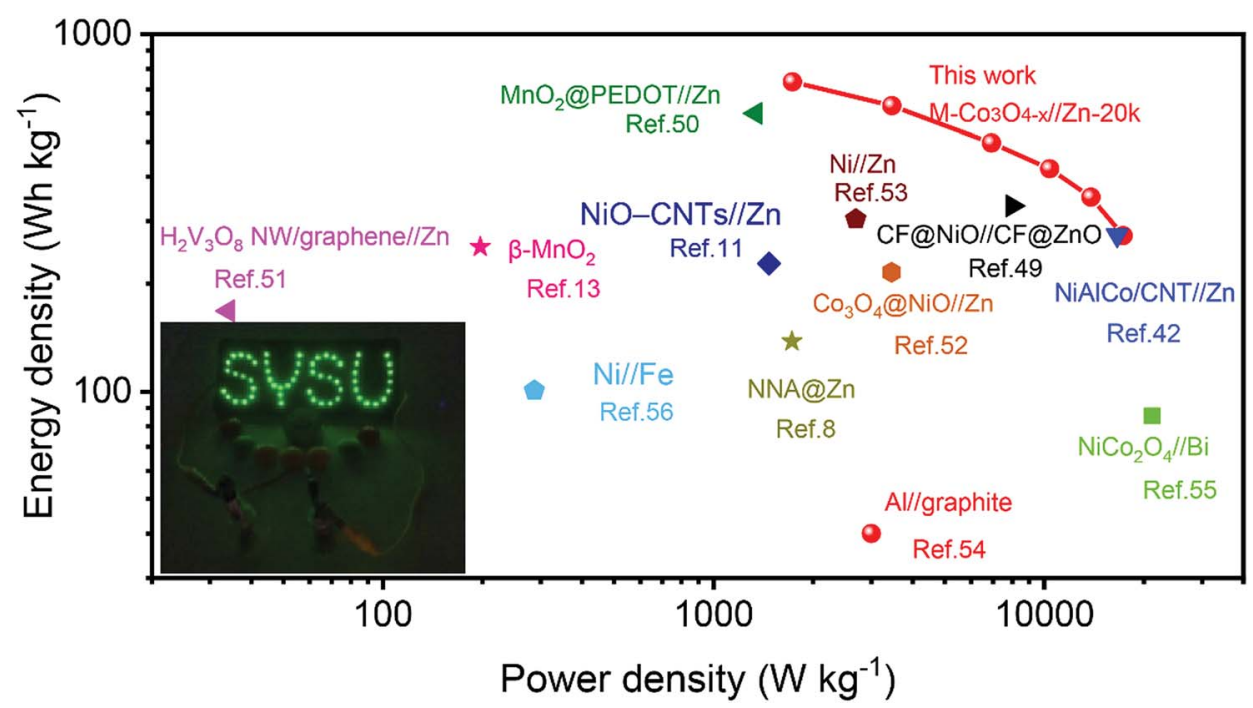

Fig. 6 Ragone plots of the $\mathrm{M}-\mathrm{CO}_{3} \mathrm{O}_{4-x} / / \mathrm{Zn}-2 \mathrm{Ok}$ battery. The values reported for other aqueous batteries are added for comparison. The inset is a photograph of a neon sign powered by two $\mathrm{M}-\mathrm{CO}_{3} \mathrm{O}_{4-x} / / \mathrm{Zn}$ battery devices.

Fig. 6 presents the Ragone plots of $\mathrm{M}-\mathrm{Co}_{3} \mathrm{O}_{4-x} / / \mathrm{Zn}-20 \mathrm{k}$ with the comparison of energy and power densities of other reported aqueous batteries. Encouragingly, a remarkable energy density of $722.4 \mathrm{~W} \mathrm{~h} \mathrm{~kg}^{-1}$ at a power density of $1.73 \mathrm{~kW} \mathrm{~kg}^{-1}$ (based on the mass of the $\mathrm{M}^{-} \mathrm{Co}_{3} \mathrm{O}_{4-x}$ cathode) is achieved by the M$\mathrm{Co}_{3} \mathrm{O}_{4-x} / / \mathrm{Zn}$-20k battery. Such an ultrahigh energy density of the $\mathrm{M}-\mathrm{Co}_{3} \mathrm{O}_{4-x} / / \mathrm{Zn}-20 \mathrm{k}$ battery surpasses that of lots of recently reported $\mathrm{Zn}$-based batteries and other aqueous batteries, such as the NiAlCo/CNT//Zn battery $\left(274 \mathrm{~W} \mathrm{~h} \mathrm{~kg}^{-1}\right.$ at $\left.16.6 \mathrm{~kW} \mathrm{~kg}^{-1}\right),{ }^{42}$

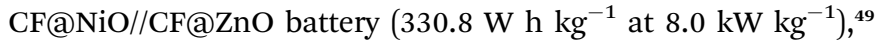
$\mathrm{MnO}_{2} @ P E D O T / / \mathrm{Zn}$ battery (599.8 $\mathrm{W} \mathrm{h} \mathrm{kg}^{-1}$ at $\left.1.34 \mathrm{~kW} \mathrm{~kg}^{-1}\right),{ }^{50}$ $\mathrm{NiO}-\mathrm{CNTs} / / \mathrm{Zn}\left(228 \mathrm{~W} \mathrm{~h} \mathrm{~kg}{ }^{-1}\right.$ at $\left.1.47 \mathrm{~kW} \mathrm{~kg}^{-1}\right),{ }^{11} \mathrm{H}_{2} \mathrm{~V}_{3} \mathrm{O}_{8} \mathrm{NW} /$ graphene//Zn $\left(168 \mathrm{~W} \mathrm{~h} \mathrm{~kg}^{-1}\right.$ at $\left.0.034 \mathrm{~kW} \mathrm{~kg}^{-1}\right),{ }^{51} \beta-\mathrm{MnO}_{2}(254 \mathrm{~W}$ $\mathrm{h} \mathrm{kg}^{-1}$ at $\left.197 \mathrm{~W} \mathrm{~kg}^{-1}\right),{ }^{13} \mathrm{Co}_{3} \mathrm{O}_{4} @ \mathrm{NiO} / / \mathrm{Zn}$ battery $(215.5 \mathrm{~W} \mathrm{~h}$ $\mathrm{kg}^{-1}$ at $\left.3.45 \mathrm{~kW} \mathrm{~kg}{ }^{-1}\right),{ }^{52} \mathrm{NNA} @ Z n\left(148.54 \mathrm{~W} \mathrm{~h} \mathrm{~kg}^{-1}\right.$ at a power density of $\left.1725 \mathrm{~W} \mathrm{~kg}^{-1}\right),{ }^{8} \mathrm{Ni} / / \mathrm{Zn}\left(303.8 \mathrm{~W} \mathrm{~h} \mathrm{~kg}^{-1}\right.$ at $2.69 \mathrm{~kW}$ $\left.\mathrm{kg}^{-1}\right),{ }^{53} \mathrm{Al} / /$ graphite $\mathrm{Al}$ ion battery $\left(40 \mathrm{~W} \mathrm{~h} \mathrm{~kg}{ }^{-1}\right.$ at $3.0 \mathrm{~kW}$ $\left.\mathrm{kg}^{-1}\right),{ }^{54} \mathrm{NiCo}_{2} \mathrm{O}_{4} / / \mathrm{Bi}$ battery $\left(85.5 \mathrm{~W} \mathrm{~h} \mathrm{~kg}^{-1}\right.$ at $\left.21.2 \mathrm{~kW} \mathrm{~kg}^{-1}\right),{ }^{55}$ $\mathrm{Ni} / / \mathrm{Fe}$ battery $\left(100.7 \mathrm{~W} \mathrm{~h} \mathrm{~kg}^{-1}\right.$ at $\left.0.287 \mathrm{~kW} \mathrm{~kg}^{-1}\right),{ }^{56}$ and $\mathrm{Zn} / /$ $\mathrm{LiNi}_{1 / 3} \mathrm{Co}_{1 / 3} \mathrm{Mn}_{1 / 3} \mathrm{O}_{2}\left(154 \mathrm{~W} \mathrm{~h} \mathrm{~kg}{ }^{-1}\right.$ at $\left.0.5 \mathrm{C}\right) .^{57}$ Furthermore, to verify its potential application, two as-fabricated $\mathrm{M}-\mathrm{Co}_{3} \mathrm{O}_{4-x} / / \mathrm{Zn}$ batteries in series are employed for charging a neon sign consisting of 57 light-emitting diodes (Fig. 6 inset).

\section{Conclusion}

In summary, we have developed an efficient structural and defect engineering strategy for designing 3D ordered mesoporous and oxygen-vacancy nanoarchitectures to significantly enhance the electrochemical performance of $\mathrm{M}^{-} \mathrm{Co}_{3} \mathrm{O}_{4-x}$ as a robust cathode for $\mathrm{Zn}$-based batteries. Benefiting from the synergetic effect of the ordered mesoporous nanoarchitecture and oxygen vacancies, the $\mathrm{M}-\mathrm{Co}_{3} \mathrm{O}_{4-x}$ electrode possesses a fast ion diffusion channel, short ion transport distance, high electrical conductivity, abundant active sites, strong $\mathrm{OH}^{-}$ adsorption capacity and highly stabilized structure. As a result, the fabricated optimal $\mathrm{M}-\mathrm{Co}_{3} \mathrm{O}_{4-x} / / \mathrm{Zn}$ battery presents a considerable capacity of $384 \mathrm{~mA} \mathrm{~h} \mathrm{~g}{ }^{-1}$ at $1 \mathrm{~A} \mathrm{~g}^{-1}$, which is about 8-fold greater than that of the pristine $\mathrm{Co}_{3} \mathrm{O}_{4} / / \mathrm{Zn}$ battery $\left(50 \mathrm{~mA} \mathrm{~h} \mathrm{~g}{ }^{-1}\right)$. In addition, the $\mathrm{M}^{-} \mathrm{Co}_{3} \mathrm{O}_{4-x} / / \mathrm{Zn}-20 \mathrm{k}$ battery shows an extraordinary energy density of $722.4 \mathrm{~W} \mathrm{~h} \mathrm{~kg}^{-1}$ at a power density of $1.73 \mathrm{~kW} \mathrm{~kg}^{-1}$. Furthermore, the rechargeable $\mathrm{M}-\mathrm{Co}_{3} \mathrm{O}_{4-x} / / \mathrm{Zn}$ battery possesses unprecedented cycling stability without any capacity decay after 60000 cycles. This 3D ordered mesoporous structural and oxygen-vacancy defect engineering is an effective strategy to design ultrahigh energy density and super durable cathode materials for ZBBs, which can also be extended for other metal oxide and metal sulfide electrode materials.

\section{Experimental section}

\section{Preparation of $\mathrm{M}-\mathrm{Co}_{3} \mathrm{O}_{4-x}, \mathrm{M}-\mathrm{Co}_{3} \mathrm{O}_{4}, \mathrm{Co}_{3} \mathrm{O}_{4}$ and $\mathrm{Co}_{3} \mathrm{O}_{4-x}$}

Three-dimensional mesoporous silica (KIT-6) with Ia3d symmetry is used as a hard template. The synthesis of mesoporous KIT- 6 has been described in previous reports. ${ }^{58} \mathrm{~A}$ facile high isostatic assisted nanocasting is used to prepare ordered mesoporous $\mathrm{Co}_{3} \mathrm{O}_{4}\left(\mathrm{M}-\mathrm{Co}_{3} \mathrm{O}_{4}\right): 1 \mathrm{~g}$ KIT-6 powder as the template is first degassed at $400{ }^{\circ} \mathrm{C}$ under dynamic vacuum for $3 \mathrm{~h}$ and then impregnated with a solution of $\mathrm{Co}\left(\mathrm{NO}_{3}\right)_{2} \cdot 6 \mathrm{H}_{2} \mathrm{O}(\mathrm{wt} \%$ : $60 \%)$ at room temperature under reduced pressure. Subsequently the above mixture is poured into isostatic-pressing equipment (Fig. S21†), and then exposed to $300 \mathrm{MPa}$ impregnation pressure for several minutes. The excrescent $\mathrm{Co}\left(\mathrm{NO}_{3}\right)_{2}-$ $\cdot 6 \mathrm{H}_{2} \mathrm{O}$ solution is filtered, and the resulting material is calcined at $500{ }^{\circ} \mathrm{C}$ for $6 \mathrm{~h}$ in air with a heating rate of $1{ }^{\circ} \mathrm{C} \mathrm{min}{ }^{-1}$. Then the resulting complex (KIT-6@ $\left.\mathrm{Co}_{3} \mathrm{O}_{4}\right)$ is twice treated with a $2 \mathrm{M}$ $\mathrm{NaOH}$ solution at $60{ }^{\circ} \mathrm{C}$ to remove the silica template, followed by washing with deionized water several times, and then drying at $60{ }^{\circ} \mathrm{C}$. To obtain $\mathrm{M}-\mathrm{Co}_{3} \mathrm{O}_{4-x}$, the as-prepared $\mathrm{M}-\mathrm{Co}_{3} \mathrm{O}_{4}$ is 
annealed in a $\mathrm{N}_{2}$ atmosphere in the presence of $\mathrm{NaH}_{2} \mathrm{PO}_{2} \cdot \mathrm{H}_{2} \mathrm{O}$

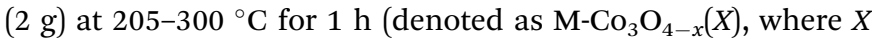
represents the treatment temperature, while the sample treated at $250{ }^{\circ} \mathrm{C}$ is denoted as $\mathrm{M}-\mathrm{Co}_{3} \mathrm{O}_{4-x}$ in the text).

The non-porous nanoparticle $\mathrm{Co}_{3} \mathrm{O}_{4}$ (denoted as $\mathrm{Co}_{3} \mathrm{O}_{4}$ ) is obtained by directly calcining the $\mathrm{Co}\left(\mathrm{NO}_{3}\right)_{2} \cdot 6 \mathrm{H}_{2} \mathrm{O}$ precursor at $500{ }^{\circ} \mathrm{C}$ for $6 \mathrm{~h}$ in air. The non-porous oxygen-vacancy $\mathrm{Co}_{3} \mathrm{O}_{4-x}$ (denoted as $\mathrm{Co}_{3} \mathrm{O}_{4-x}$ ) is prepared by using the same method as that of $\mathrm{M}-\mathrm{Co}_{3} \mathrm{O}_{4-x}$.

\section{Material characterization}

The microstructures and compositions of the electrode materials are analyzed using $\mathrm{N}_{2}$ adsorption (Micromeritics ASAP 2020 PLUS HD88), Field-Emission-SEM (Zeiss/Bruker, Gemini500), a Spherical Aberration Corrected Transmission Electron Microscope (JEM-ARM200P), Raman spectroscopy (Renishaw in Via), XPS (ESCALab250, Thermo VG), and XRD (SmartLab). EPR tests are carried out in the $\mathrm{X}$ band $(9.45 \mathrm{GHz})$ with a $5.00 \mathrm{G}$ modulation amplitude and a magnetic field modulation of $100 \mathrm{kHz}$ using a Bruker EPR spectrometer (A300-10-12, Bruker) at $77 \mathrm{~K}$.

\section{Electrochemical measurements}

Cathode electrodes are prepared by mixing samples with the polyvinylidene fluoride (PVDF) binder (AR, Sigma-Aldrich) and carbon black (AR, Sigma-Aldrich) in a weight ratio of $7: 2: 1$ in 1-methyl-2-pyrrolidinone until a homogeneous slurry is formed. The slurry is painted on nickel foam, and then the electrode is dried overnight at $333 \mathrm{~K}$ in a vacuum, and thereafter mechanically pressed under a pressure of $1 \mathrm{MPa}$ for several seconds. The active material on nickel foam has a geometric area of 0.5 $\mathrm{cm}^{2}(0.5 \mathrm{~cm} \times 1.0 \mathrm{~cm})$, and the active mass loading of the electrode is $1.2 \mathrm{mg} \mathrm{cm}^{-2}$.

Commercial $\mathrm{Zn}$ foil is directly used as the anode without any treatment. The weight ratio of $\mathrm{Zn}$ and $\mathrm{Co}_{3} \mathrm{O}_{4}$ is about $170: 1$. CV, GCD measurements and electrochemical impedance spectroscopy are conducted using an electrochemical workstation (CHI 760E). The electrochemical characterization of the aqueous $\mathrm{M}-\mathrm{Co}_{3} \mathrm{O}_{4-x} / / \mathrm{Zn}, \quad \mathrm{M}-\mathrm{Co}_{3} \mathrm{O}_{4} / / \mathrm{Zn}, \quad \mathrm{Co}_{3} \mathrm{O}_{4-x} / / \mathrm{Zn}$ and $\mathrm{Co}_{3} \mathrm{O}_{4} / / \mathrm{Zn}$ batteries is performed in a two-electrode cell in an electrolyte solution of $6 \mathrm{M} \mathrm{KOH}$ with $0.2 \mathrm{M} \mathrm{Zn(Ac})_{2}$, with cobaltosic oxide as the cathode and zinc foil as the anode.

\section{Conflicts of interest}

There are no conflicts to declare.

\section{Acknowledgements}

This work was supported by the Youth 1000 Talents Program of China, the National Natural Science Foundation of China (No. 21601211, 21805316, 21822509, and U1810110), the Tip-top Scientific and Technical Innovative Youth Talents of Guangdong Special Support Program (2015TQ01C205), and the Pearl River Nova Program of Guangzhou (201610010080).

\section{Notes and references}

1 N. S. Choi, Z. Chen, S. A. Freunberger, X. Ji, Y. K. Sun, K. Amine, G. Yushin, L. F. Nazar, J. Cho and P. G. Bruce, Angew. Chem., Int. Ed. Engl., 2012, 51, 9994.

2 V. Etacheri, R. Marom, R. Elazari, G. Salitra and D. Aurbach, Energy Environ. Sci., 2011, 4, 3243.

3 D. Bruce, K. Haresh and T. Jean-Marie, Science, 2011, 334, 928.

4 C. Xia, J. Guo, P. Li, X. Zhang and H. N. Alshareef, Angew. Chem., Int. Ed. Engl., 2018, 57, 3943.

5 G. Fang, J. Zhou, A. Pan and S. Liang, ACS Energy Lett., 2018, 3,2480 .

6 H. Kim, G. Jeong, Y. U. Kim, J. H. Kim, C. M. Park and H. J. Sohn, Chem. Soc. Rev., 2013, 42, 9011.

7 X. Wang, F. Wang, L. Wang, M. Li, Y. Wang, B. Chen, Y. Zhu, L. Fu, L. Zha, L. Zhang, Y. Wu and W. Huang, Adv. Mater., 2016, 28, 4904.

8 C. Xu, J. Liao, C. Yang, R. Wang, D. Wu, P. Zou, Z. Lin, B. Li, F. Kang and C.-P. Wong, Nano Energy, 2016, 30, 900.

9 M. Song, H. Tan, D. Chao and H. J. Fan, Adv. Funct. Mater., 2018, 28, 1802564.

10 L. Ma, S. Chen, H. Li, Z. Ruan, Z. Tang, Z. Liu, Z. Wang, Y. Huang, Z. Pei, J. A. Zapien and C. Zhi, Energy Environ. Sci., 2018, 11, 2521.

11 X. Wang, M. Li, Y. Wang, B. Chen, Y. Zhu and Y. Wu, J. Mater. Chem. A, 2015, 3, 8280.

12 J. Zhou, L. Shan, Z. Wu, X. Guo, G. Fang and S. Liang, Chem. Commun., 2018, 54, 4457.

13 N. Zhang, F. Cheng, J. Liu, L. Wang, X. Long, X. Liu, F. Li and J. Chen, Nat. Commun., 2017, 8, 1.

14 F. Mo, G. Liang, Q. Meng, Z. Liu, H. Li, J. Fan and C. Zhi, Energy Environ. Sci., 2019, 12, 706-715.

15 L. Ma, S. Chen, Z. Pei, H. Li, Z. Wang, Z. Liu, Z. Tang, J. A. Zapien and C. Zhi, ACS Nano, 2018, 12, 8597-8605.

16 H. Du, K. Huang, M. Li, Y. Xia, Y. Sun, M. Yu and B. Geng, Nano Res., 2018, 11, 1490.

17 M. Yu, W. Wang, C. Li, T. Zhai, X. Lu and Y. Tong, NPG Asia Mater., 2014, 6, 129.

18 C. Guan, Y. Wang, M. Zacharias, J. Wang and H. J. Fan, Nanotechnology, 2015, 26, 014001.

19 Q. Wang, B. Yu, X. Li, L. Xing and X. Xue, J. Mater. Chem. A, 2016, 4, 425.

20 W. Zong, F. Lai, G. He, J. Feng, W. Wang, R. Lian, Y. E. Miao, G. C. Wang, I. P. Parkin and T. Liu, Small, 2018, 14, 1801562.

21 J. Wang, R. Gao, D. Zhou, Z. Chen, Z. Wu, G. Schumacher, Z. Hu and X. Liu, ACS Catal., 2017, 7, 6533.

22 C. Teng, Y. Han, G. Fu, J. Hu, H. Zheng, X. Lu and J. Jiang, J. Mater. Chem. A, 2018, 6, 18938-18947.

23 Z. Cai, Y. Bi, E. Hu, W. Liu, N. Dwarica, Y. Tian, X. Li, Y. Kuang, Y. Li, X.-Q. Yang, H. Wang and X. Sun, Adv. Energy Mater., 2018, 8, 1701694.

24 J. Luo, J. Zhang and Y. Xia, Cheminform, 2010, 38, 5618.

25 L. Sun, Q. Deng, Y. Li, H. Mi, S. Wang, L. Deng, X. Ren and P. Zhang, Electrochim. Acta, 2017, 241, 252. 
26 Y. Zhang, B. Ouyang, J. Xu, G. Jia, S. Chen, R. S. Rawat and H. J. Fan, Angew. Chem., Int. Ed. Engl., 2016, 55, 8670-8674.

27 M. Cheng, S. Duan, H. Fan, X. Su, Y. Cui and R. Wang, Chem. Eng. J., 2017, 327, 100.

28 C. Hu, L. Zhang, Z. J. Zhao, J. Luo, J. Shi, Z. Huang and J. Gong, Adv. Mater., 2017, 29, 1701820.

29 N. S. McIntyre and M. G. Cook, Anal. Chem., 1975, 47, 2208.

30 C. Guan, X. Liu, W. Ren, X. Li, C. Cheng and J. Wang, Adv. Energy Mater., 2017, 7, 1602391.

31 C. Zhu, S. Fu, D. Du and Y. Lin, Chemistry, 2016, 22, 4000.

32 T. Zhai, L. Wan, S. Sun, Q. Chen, J. Sun, Q. Xia and H. Xia, Adv. Mater., 2017, 29, 1604167.

33 M. S. Hamdy, I. S. Yahia, W. Knoff and T. Story, Optik, 2018, 158, 1123.

34 Y. Dou, J. Xu, B. Ruan, Q. Liu, Y. Pan, Z. Sun and S. X. Dou, Adv. Energy Mater., 2016, 6, 1501835.

35 B. Wu, G. Zhang, M. Yan, T. Xiong, P. He, L. He, X. Xu and L. Mai, Small, 2018, 14, 1703850.

36 N. Zhang, F. Cheng, Y. Liu, Q. Zhao, K. Lei, C. Chen, X. Liu and J. Chen, J. Am. Chem. Soc., 2016, 138, 12894.

37 P. He, M. Yan, G. Zhang, R. Sun, L. Chen, Q. An and L. Mai, Adv. Energy Mater., 2017, 7, 1601920.

38 J. Huang, Z. Wang, M. Hou, X. Dong, Y. Liu, Y. Wang and Y. Xia, Nat. Commun., 2018, 9, 2906.

39 Y. Cai, F. Liu, Z. Luo, G. Fang, J. Zhou, A. Pan and S. Liang, Energy Storage Materials, 2018, 13, 168-174.

40 B. Zhang, Y. Liu, X. Wu, Y. Yang, Z. Chang, Z. Wen and Y. Wu, Chem. Commun., 2014, 50, 1209-1211.

41 F. Wang, F. Yu, X. Wang, Z. Chang, L. Fu, Y. Zhu, Z. Wen, Y. Wu and W. Huang, ACS Appl. Mater. Interfaces, 2016, 8, 9022-9029.

42 M. Gong, Y. Li, H. Zhang, B. Zhang, W. Zhou, J. Feng, H. Wang, Y. Liang, Z. Fan, J. Liu and H. Dai, Energy Environ. Sci., 2014, 7, 2025.
43 J. D. Benck, Z. Chen, L. Y. Kuritzky, A. J. Forman and T. F. Jaramillo, ACS Catal., 2012, 2, 1916.

44 M. Yu, Z. Wang, C. Hou, Z. Wang, C. Liang, C. Zhao, Y. Tong, X. Lu and S. Yang, Adv. Mater., 2017, 29, 1602868.

45 Y. Zeng, Z. Lai, Y. Han, H. Zhang, S. Xie and X. Lu, Adv. Mater., 2018, 30, 1802396.

46 S. B. Tang, M. O. Lai and L. Lu, J. Alloys Compd., 2008, 449, 300.

47 T. Zhai, S. Xie, M. Yu, P. Fang, C. Liang, X. Lu and Y. Tong, Nano Energy, 2014, 8, 255-263.

48 E. Ventosa, W. Xia, S. Klink, F. La Mantia, B. Mei, M. Muhler and W. Schuhmann, Chemistry, 2013, 19, 14194-14199.

49 J. Liu, C. Guan, C. Zhou, Z. Fan, Q. Ke, G. Zhang, C. Liu and J. Wang, Adv. Mater., 2016, 28, 8732.

50 Y. Zeng, X. Zhang, Y. Meng, M. Yu, J. Yi, Y. Wu, X. Lu and Y. Tong, Adv. Mater., 2017, 29, 1700274.

51 Q. Pang, C. Sun, Y. Yu, K. Zhao, Z. Zhang, P. M. Voyles, G. Chen, Y. Wei and X. Wang, Adv. Energy Mater., 2018, 8, 1800144.

52 Z. Lu, X. Wu, X. Lei, Y. Li and X. Sun, Inorg. Chem. Front., 2015, 2, 184.

53 H. Zhang, X. Zhang, H. Li, Y. Zhang, Y. Zeng, Y. Tong, P. Zhang and X. Lu, Green Energy Environment, 2018, 3, 56.

54 M. C. Lin, M. Gong, B. Lu, Y. Wu, D. Y. Wang, M. Guan, M. Angell, C. Chen, J. Yang, B. J. Hwang and H. Dai, Nature, 2015, 520, 325.

55 Y. Zeng, Z. Lin, Y. Meng, Y. Wang, M. Yu, X. Lu and Y. Tong, Adv. Mater., 2016, 28, 9188.

56 J. Liu, M. Chen, L. Zhang, J. Jiang, J. Yan, Y. Huang, J. Lin, H. J. Fan and Z. X. Shen, Nano Lett., 2014, 14, 7180.

57 F. Wang, Y. Liu, X. Wang, Z. Chang, Y. Wu and R. Holze, ChemElectroChem, 2015, 2, 1024-1030.

58 F. Kleitz, S. Hei Choi and R. Ryoo, Chem. Commun., 2003, 17, 2136. 